\title{
Feet positioning in the semi-static postural evaluation through photogrammetry: a systematic review
}

\author{
Arthur Antoniolli ${ }^{1}$, Liliane Martini Araújo Ducati ${ }^{1}$, Emanuelle Francine Detogni Schmit ${ }^{1}$, \\ Cláudia Tarragô Candotti ${ }^{1}$
}

\begin{abstract}
Photogrammetry is a relatively simple and objective instrument of evaluation that provides accurate and reproducible quantitative results, if applied rigorously, existing nowadays several protocols. The main purpose was to systematically review the utilized feet positioning to conduct a semi-static postural evaluation through photogrammetry. It was performed a systematic review of observational studies and clinic trials using the keywords "photogrammetry" and "spinal postural evaluation" to conduct searches on scientific databases. The eligibility criteria adopted were: utilize the photogrammetry to evaluate children, teenagers, adults or elders with or without pathologies; explicit the utilized feet positioning to conduct the evaluation; and be written in English, Portuguese or Spanish. The methodological quality was assessed by Downs and Black scale and the strength of evidence by the best evidence synthesis. It was found 1.786 articles and 40 were included in this review. The main feet positioning found were: self-referred, separated and in parallel, united and in parallel and standard self-referred. The review exhibited strong strength of evidence in the methodological quality assessment. Considering the main feet positioning found, it is considered primordial that the selection of evaluation methodology respects the specific instructions of each analysis protocol or software.

Keywords: Photogrammetry, Posture, Review.
\end{abstract}

\section{INTRODUCTION}

The body posture is a complex and hard to measure phenomenon, its evaluation is the first step to any physical or physiotherapy intervention (Iunes et al., 2005). One option to this type of evaluation is the computerized photogrammetry, an objective method that is reasonably simple and provides accurate and reproducible quantitative results of easy understanding (Belli, Chaves, de Oliveira, \& Grossi, 2009; Fortin et al., 2012; Moradi et al., 2014).

The photogrammetry protocols exhibit some discrepancies in between, as the feet positioning, for example. On some protocols it is self-referred by the evaluated individual, in which the individual stands in the most comfortable position (Ferreira et al., 2010). In others, the position is previously determined. There is also diversity in the supporting base shape, being more acute (Furlanetto, Candotti, Comerlato, \&
Loss, 2012) or obtuse (Kendall, McCreary, \& Provance, 1995). Considering the feet as the body supporting base, its position might influence the variables of the posture and consequently the result. Therefore, the comparison of results of different studies, epidemiological or experimental, that utilize photogrammetry is difficult. The solution to this problem initially rests in the clever use of many feet positioning possibilities proposed by different protocols and software of evaluation. In this context, the objective of this study was to identify, from a systematic review, the feet positioning to conduct a semi-static postural evaluation through photogrammetry, pointing out positive and negative aspects of each position, as well as identifying the existence or not of an ideal position of feet for the postural evaluation. It is expected that the results of this systematic review assist to support the selection of an evaluation protocol and consequently feet positioning to be

\footnotetext{
Manuscript received at June10 ${ }^{\text {th }} 2016$; Accepted at June25 2017

${ }^{1}$ Universidade Federal do Rio Grande do Sul, UFRGS, Porto Alegre, RS, Brasil

*Corresponding author: Av. Paulo Gama, 110 - Farroupilha, Porto Alegre - RS, 90040-060, Brasil E-mail: tuianto@hotmail.com
} 
used by health professionals in the clinical and scientific practice according to their reality.

\section{METHOD}

\section{Research design}

This study comprehended a systematic review of literature (Galvão \& Pereira, 2014) directed by PRISMA Statement (Moher et al., 2009), based on the recommendations of Cochrane (Higgins \& Green, 2011) collaboration, which has been registered in PROSPERO (http://www.crd.york.ac.uk/PROSPERO/display _record.asp? ID $=$ CRD42015026298) under the code CRD42015026298.

\section{Search strategy}

With the intention of identify the studies of interest, duplicated but independent searches were executed on the PubMed, Science, Scopus, Embase and Bireme databases, from the beginning of the bases until September the $23^{\text {th }}$, 2015. The key words applied were "photogrammetry" and "spinal postural evaluation". An example of search strategy is demonstrated in the Figure 1.

\begin{tabular}{l|l}
\hline$\# 1$ & $\begin{array}{l}\text { "Photogrammetry" OR "Photogrammetries" OR "Stereophotogrammetry" OR } \\
\text { "Stereophotogrammetries" or "Digital Analysis" OR "Digital Photographs" OR "Digital } \\
\text { photography" }\end{array}$ \\
\hline \#2 & $\begin{array}{l}\text { "Spinal postural evaluation" OR "Spinal postural assessment" OR "Postural evaluation" OR } \\
\text { OR "Postural valuation" OR "Postural appraisal" OR "Postural appraisement" OR "Postural } \\
\text { evaluations" OR "Quantitative evaluation" OR "Evaluation, Quantitative" OR "Evaluations, } \\
\text { Quantitative" OR "Quantitative Evaluations" }\end{array}$ \\
\hline$\# 3$ & \#1 AND \#2 \\
\hline
\end{tabular}

Figure 1. Search strategy applied on the EMBASE database.

\section{Eligibility criteria}

With the purpose of selecting the articles that were found, the following eligibility criteria were established: (1) the study is a clinic trial or has a observational methodological design; (2) conduct semi-static posture evaluation through photogrammetry; (3) sample composed by children, teenagers, adults or elders with or without pathologies; (4)the utilized feet positioning in the evaluation should be explicit by text or image; and (5) be written in English, Portuguese or Spanish.

Every article found in the searches on the databases were analysed in the first phase, which consisted in the reading of all titles and abstracts by two independent evaluators and selection of those that presented potential to fulfil the eligibility criteria according to what was read. The second phase consisted in the full reading of the selected articles in the previous stage by the same two independent evaluators and selection of those that indeed fulfilled the eligibility criteria. In the third phase, both independent evaluators consulted the bibliographic references of the selected articles in phase two with the intention of locating articles that were not found in the searches on the databases. The discrepancies between evaluators regarding the articles were settled by consensus.

\section{Data extraction}

Both independent evaluators used an elaborated standard form to extract the data from the studies that were included in this review. The main items of extracted information were: authors; year of publication; utilized feet positioning; sample; utilized software or protocol in the evaluation; evaluated photographic planes; and corporal segments analysed. After the independent data extraction, the information contained in both forms was compiled into one united form. The discrepancies between information of the independent forms were discussed and verified in the original data of the studies by the evaluators in order to obtain consensus. 
64 |A Antoniolli, LMA Ducati, EFD Schmit, CT Candotti

Table 1

Rating and the score of each study in the evaluation of methodological quality by downs and Black Scale

\begin{tabular}{|c|c|c|c|c|c|c|c|c|c|c|c|c|c|c|c|c|c|c|c|c|c|c|c|c|c|c|c|c|c|c|}
\hline First author (year) & 인 & ㅇ & ¿ & \& & 요 & ৪ & 이 & 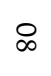 & 8 & ๖ & こ & $\vec{N}$ & $\breve{\omega}$ & $\vec{A}$ & $\vec{v}$ & ๘ & $\vec{v}$ & $\infty$ & 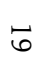 & N & $\stackrel{\sim}{\sim}$ & N & $\widetilde{\omega}$ & $\stackrel{N}{A}$ & $\tilde{N}$ & N & 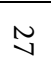 & $\begin{array}{c}\mathrm{N}^{\circ} \text { of } \\
\sqrt{ }\end{array}$ & $\begin{array}{c}\% \text { of } \\
\text { quality }\end{array}$ & $\begin{array}{l}\text { High } \\
\text { quality }\end{array}$ \\
\hline Barbosa (2013) & $\sqrt{ }$ & $\sqrt{ }$ & $\sqrt{ }$ & \# & \# & $\sqrt{ }$ & $\sqrt{ }$ & \# & $\sqrt{ }$ & $\sqrt{ }$ & $\sqrt{ }$ & $\sqrt{ }$ & \# & \# & \# & $\sqrt{ }$ & \# & $\mathrm{X}$ & \# & $\sqrt{ }$ & \# & \# & \# & \# & \# & \# & \# & 11 & 91.6 & Yes \\
\hline Batistão (2014) & $\sqrt{ }$ & $\checkmark$ & $\checkmark$ & \# & \# & $\checkmark$ & $\sqrt{ }$ & \# & $\mathrm{X}$ & $\sqrt{ }$ & $\sqrt{ }$ & $\sqrt{ }$ & \# & \# & \# & $\sqrt{ }$ & \# & $\sqrt{ }$ & \# & $\sqrt{ }$ & \# & \# & \# & \# & \# & \# & \# & 11 & 91.6 & Yes \\
\hline Belli (2009) & $\sqrt{ }$ & $\checkmark$ & $\checkmark$ & \# & \# & $\checkmark$ & $\sqrt{ }$ & \# & $\checkmark$ & $\sqrt{ }$ & $\checkmark$ & $\checkmark$ & \# & \# & \# & $\sqrt{ }$ & \# & $\sqrt{ }$ & \# & $\sqrt{ }$ & \# & \# & \# & \# & \# & \# & \# & 12 & 100 & Yes \\
\hline Carregaro (2012) & $\sqrt{ }$ & $\sqrt{ }$ & $\checkmark$ & \# & \# & $\sqrt{ }$ & $\checkmark$ & \# & $\checkmark$ & $\mathrm{X}$ & $\sqrt{ }$ & $\mathrm{X}$ & \# & \# & \# & $\sqrt{ }$ & \# & $\sqrt{ }$ & \# & $\sqrt{ }$ & \# & \# & \# & \# & \# & \# & \# & 10 & 83.3 & Yes \\
\hline Cerruto (2012) & $\sqrt{ }$ & $\checkmark$ & $\checkmark$ & $\sqrt{ }$ & $\mathrm{X}$ & $\checkmark$ & $\sqrt{ }$ & $\mathrm{X}$ & $\sqrt{ }$ & $\sqrt{ }$ & $\checkmark$ & $\checkmark$ & $\checkmark$ & $\checkmark$ & $\mathrm{X}$ & $\sqrt{ }$ & $\mathrm{X}$ & $\sqrt{ }$ & $\checkmark$ & $\sqrt{ }$ & $\sqrt{ }$ & $\mathrm{X}$ & $\sqrt{ }$ & $\checkmark$ & $\checkmark$ & $\checkmark$ & $\mathrm{X}$ & 21 & 77.7 & Yes \\
\hline Chiao Yi (2008) & $\sqrt{ }$ & $\checkmark$ & $\sqrt{ }$ & \# & \# & $\checkmark$ & $\sqrt{ }$ & \# & $\checkmark$ & $\sqrt{ }$ & $\sqrt{ }$ & $\mathrm{X}$ & \# & \# & \# & $\sqrt{ }$ & \# & $\sqrt{ }$ & \# & $\mathrm{X}$ & \# & \# & \# & \# & \# & \# & \# & 10 & 83.3 & Yes \\
\hline Coelho (2013) & $\sqrt{ }$ & $\checkmark$ & $\checkmark$ & \# & \# & $\checkmark$ & $\checkmark$ & \# & $\checkmark$ & $\checkmark$ & $\checkmark$ & $\mathrm{X}$ & \# & \# & \# & $\checkmark$ & \# & $\sqrt{ }$ & \# & $\sqrt{ }$ & \# & \# & \# & \# & \# & \# & \# & 11 & 91.6 & Yes \\
\hline Coelho (2014) & $\sqrt{ }$ & $\checkmark$ & $\checkmark$ & \# & \# & $\checkmark$ & v & \# & $\checkmark$ & $\sqrt{ }$ & $\checkmark$ & $\mathrm{X}$ & \# & \# & \# & $\checkmark$ & \# & $\sqrt{ }$ & \# & $\checkmark$ & \# & \# & \# & \# & \# & \# & \# & 11 & 91.6 & Yes \\
\hline Corrêa (2007) & $\sqrt{ }$ & $\sqrt{ }$ & $\checkmark$ & $\sqrt{ }$ & $\mathrm{X}$ & $\sqrt{ }$ & $\checkmark$ & $\mathrm{X}$ & $\sqrt{ }$ & $\sqrt{ }$ & $\mathrm{X}$ & $\mathrm{X}$ & $\checkmark$ & $\mathrm{X}$ & $\mathrm{X}$ & $\sqrt{ }$ & $\checkmark$ & $\sqrt{ }$ & $\sqrt{ }$ & $\sqrt{ }$ & $\mathrm{X}$ & $\mathrm{X}$ & $\mathrm{X}$ & $\mathrm{X}$ & $\mathrm{X}$ & $\mathrm{X}$ & $\mathrm{X}$ & 14 & 51.85 & No \\
\hline de Almeida (2012) & $\sqrt{ }$ & $\sqrt{ }$ & $\sqrt{ }$ & \# & \# & $\sqrt{ }$ & $\sqrt{ }$ & \# & $\sqrt{ }$ & $\sqrt{ }$ & $\sqrt{ }$ & $\sqrt{ }$ & \# & \# & \# & $\sqrt{ }$ & \# & $\sqrt{ }$ & \# & $\sqrt{ }$ & \# & \# & \# & \# & \# & \# & \# & 12 & 100 & Yes \\
\hline Dunk (2005) & $\sqrt{ }$ & $\checkmark$ & $\checkmark$ & \# & \# & $\sqrt{ }$ & $\checkmark$ & \# & $\checkmark$ & $\mathrm{X}$ & $\sqrt{ }$ & $\mathrm{X}$ & \# & \# & \# & $\sqrt{ }$ & \# & $\sqrt{ }$ & \# & $\checkmark$ & \# & \# & \# & \# & \# & \# & \# & 10 & 83.3 & Yes \\
\hline Fedorak (2003) & $\sqrt{ }$ & $\checkmark$ & $\checkmark$ & \# & \# & $\checkmark$ & v & \# & $\checkmark$ & $\sqrt{ }$ & $\mathrm{X}$ & $\mathrm{X}$ & \# & \# & \# & $\checkmark$ & \# & $\sqrt{ }$ & \# & $\mathrm{X}$ & \# & \# & \# & \# & \# & \# & \# & 9 & 75 & Yes \\
\hline Ferreira (2011) & $\sqrt{ }$ & $\sqrt{ }$ & $\mathrm{X}$ & \# & \# & $\checkmark$ & v & \# & $\checkmark$ & $\mathrm{X}$ & $\mathrm{X}$ & $\mathrm{X}$ & \# & \# & \# & $\checkmark$ & \# & $\mathrm{X}$ & \# & $\sqrt{ }$ & \# & \# & \# & \# & \# & \# & \# & 7 & 58.3 & Yes \\
\hline Figueiredo (2012) & $\sqrt{ }$ & $\sqrt{ }$ & $\sqrt{ }$ & \# & \# & $\sqrt{ }$ & $\sqrt{ }$ & \# & $\sqrt{ }$ & $\sqrt{ }$ & $\sqrt{ }$ & $\sqrt{ }$ & \# & \# & \# & $\sqrt{ }$ & \# & $\sqrt{ }$ & \# & $\sqrt{ }$ & \# & \# & \# & \# & \# & \# & \# & 12 & 100 & Yes \\
\hline Fortin (2010) & $\sqrt{ }$ & $\sqrt{ }$ & $\checkmark$ & \# & \# & $\sqrt{ }$ & $\checkmark$ & \# & $\sqrt{ }$ & $\checkmark$ & $\sqrt{ }$ & $\mathrm{X}$ & \# & \# & \# & $\checkmark$ & \# & $\mathrm{X}$ & \# & $\checkmark$ & \# & \# & \# & \# & \# & \# & \# & 10 & 83.3 & Yes \\
\hline Fortin (2012) & $\sqrt{ }$ & $\sqrt{ }$ & $\checkmark$ & \# & \# & $\sqrt{ }$ & $\sqrt{ }$ & \# & $\sqrt{ }$ & $\sqrt{ }$ & $\sqrt{ }$ & $\mathrm{X}$ & \# & \# & \# & $\sqrt{ }$ & \# & $\mathrm{X}$ & \# & $\sqrt{ }$ & \# & \# & \# & \# & \# & \# & \# & 10 & 83.3 & Yes \\
\hline Furlanetto (2011) & $\sqrt{ }$ & $\checkmark$ & $\mathrm{X}$ & \# & \# & $\sqrt{ }$ & $\mathrm{X}$ & \# & $\checkmark$ & $\sqrt{ }$ & $\sqrt{ }$ & $\mathrm{X}$ & \# & \# & \# & $\sqrt{ }$ & \# & $\sqrt{ }$ & \# & $\sqrt{ }$ & \# & \# & \# & \# & \# & \# & \# & 9 & 75 & Yes \\
\hline Furlanetto (2012) & $\sqrt{ }$ & $\sqrt{ }$ & $\checkmark$ & \# & \# & $\checkmark$ & $\sqrt{ }$ & \# & $\sqrt{ }$ & $\sqrt{ }$ & $\checkmark$ & $\mathrm{X}$ & \# & \# & \# & $\sqrt{ }$ & \# & $\sqrt{ }$ & \# & $\sqrt{ }$ & \# & \# & \# & \# & \# & \# & \# & 11 & 91.6 & Yes \\
\hline Gadotti (2010) & $\sqrt{ }$ & $\sqrt{ }$ & $\mathrm{X}$ & \# & \# & $\sqrt{ }$ & $\sqrt{ }$ & \# & $\sqrt{ }$ & $\sqrt{ }$ & $\checkmark$ & $\mathrm{X}$ & \# & \# & \# & $\sqrt{ }$ & \# & $\mathrm{X}$ & \# & $\sqrt{ }$ & \# & \# & \# & \# & \# & \# & \# & 9 & 75 & Yes \\
\hline Gadotti (2013) & $\sqrt{ }$ & $\sqrt{ }$ & $\checkmark$ & \# & \# & $\sqrt{ }$ & $\sqrt{ }$ & \# & $\checkmark$ & $\sqrt{ }$ & $\sqrt{ }$ & $\sqrt{ }$ & \# & \# & \# & $\sqrt{ }$ & \# & $\sqrt{ }$ & \# & $\sqrt{ }$ & \# & \# & \# & \# & \# & \# & \# & 12 & 100 & Yes \\
\hline Glaner (2012) & $\sqrt{ }$ & $\sqrt{ }$ & $\checkmark$ & \# & $\#$ & $\sqrt{ }$ & v & \# & $\checkmark$ & $\mathrm{x}$ & $\mathrm{x}$ & $\mathrm{X}$ & \# & \# & \# & $\sqrt{ }$ & \# & $\mathrm{X}$ & \# & $\sqrt{ }$ & \# & \# & \# & \# & \# & \# & \# & 8 & 66.6 & No \\
\hline Hanuskiewicz (2015) & $\sqrt{ }$ & $\checkmark$ & $\checkmark$ & $\sqrt{ }$ & $\mathrm{X}$ & $\checkmark$ & $\sqrt{ }$ & $\mathrm{X}$ & $\sqrt{ }$ & $\sqrt{ }$ & $\checkmark$ & $\mathrm{X}$ & $\checkmark$ & $\mathrm{X}$ & $\mathrm{X}$ & $\sqrt{ }$ & $\checkmark$ & $\sqrt{ }$ & $\sqrt{ }$ & $\sqrt{ }$ & $\sqrt{ }$ & $\checkmark$ & $\mathrm{X}$ & $\mathrm{X}$ & $\mathrm{X}$ & $\checkmark$ & $\mathrm{X}$ & 8 & 66.6 & No \\
\hline Iunes (2005) & $\sqrt{ }$ & $\sqrt{ }$ & $\sqrt{ }$ & \# & \# & $\sqrt{ }$ & $\sqrt{ }$ & \# & $\sqrt{ }$ & $\mathrm{X}$ & $\mathrm{X}$ & $\mathrm{X}$ & \# & \# & \# & $\sqrt{ }$ & \# & $\sqrt{ }$ & \# & $\sqrt{ }$ & \# & \# & \# & \# & \# & \# & \# & 9 & 75 & Yes \\
\hline Iunes (2010) & $\sqrt{ }$ & $\sqrt{ }$ & $\checkmark$ & \# & \# & $\checkmark$ & $\mathrm{X}$ & \# & $\sqrt{ }$ & $\checkmark$ & $\checkmark$ & $\mathrm{X}$ & \# & \# & \# & $\sqrt{ }$ & \# & $\sqrt{ }$ & \# & $\sqrt{ }$ & \# & \# & \# & \# & \# & \# & \# & 10 & 83.3 & Yes \\
\hline Lima (2004) & $\sqrt{ }$ & $\checkmark$ & $\checkmark$ & \# & \# & $\mathrm{X}$ & $\mathrm{x}$ & \# & $\sqrt{ }$ & $\sqrt{ }$ & $\checkmark$ & $\mathrm{X}$ & \# & \# & \# & $\mathrm{x}$ & \# & $\sqrt{ }$ & \# & $\checkmark$ & \# & \# & \# & \# & \# & \# & \# & 9 & 75 & Yes \\
\hline Lopes (2014) & $\checkmark$ & $\checkmark$ & $\checkmark$ & \# & \# & $\checkmark$ & $\checkmark$ & \# & $\sqrt{ }$ & $\checkmark$ & $\checkmark$ & $\mathrm{X}$ & \# & \# & \# & $\checkmark$ & \# & $\checkmark$ & \# & $\sqrt{ }$ & \# & \# & \# & \# & \# & \# & \# & 11 & 91.6 & Yes \\
\hline Milanesi (2011) & $\sqrt{ }$ & $\sqrt{ }$ & $\checkmark$ & \# & \# & $\sqrt{ }$ & $\sqrt{ }$ & \# & $\sqrt{ }$ & $\sqrt{ }$ & $\sqrt{ }$ & $\mathrm{X}$ & \# & \# & \# & $\sqrt{ }$ & \# & $\sqrt{ }$ & \# & $\sqrt{ }$ & \# & \# & \# & \# & \# & \# & \# & 11 & 91.6 & Yes \\
\hline Miranda (2009) & $\sqrt{ }$ & $\checkmark$ & $\checkmark$ & \# & \# & $\checkmark$ & v & \# & $\sqrt{ }$ & $\sqrt{ }$ & $\checkmark$ & $\mathrm{X}$ & \# & \# & \# & $\checkmark$ & \# & $\sqrt{ }$ & \# & $\sqrt{ }$ & \# & \# & \# & \# & \# & \# & \# & 11 & 91.6 & Yes \\
\hline Munhoz (2005) & $\sqrt{ }$ & $\sqrt{ }$ & $\checkmark$ & \# & \# & $\sqrt{ }$ & $\sqrt{ }$ & \# & $\sqrt{ }$ & $\sqrt{ }$ & $\sqrt{ }$ & $\mathrm{X}$ & \# & \# & \# & $\sqrt{ }$ & \# & $\sqrt{ }$ & \# & $\sqrt{ }$ & \# & \# & \# & \# & \# & \# & \# & 11 & 91.6 & Yes \\
\hline Pachioni (2011) & $\sqrt{ }$ & $\checkmark$ & $\checkmark$ & \# & \# & $v$ & $\sqrt{ }$ & \# & $\sqrt{ }$ & $\checkmark$ & $\sqrt{ }$ & $\mathrm{X}$ & \# & \# & \# & $\checkmark$ & \# & $\sqrt{ }$ & \# & $\sqrt{ }$ & \# & \# & \# & \# & \# & \# & \# & 11 & 91.6 & Yes \\
\hline Pezzan (2011) & $\sqrt{ }$ & $\sqrt{ }$ & $\sqrt{ }$ & \# & \# & $\sqrt{ }$ & $\sqrt{ }$ & \# & $\sqrt{ }$ & $\sqrt{ }$ & $\sqrt{ }$ & $\mathrm{X}$ & \# & \# & \# & $\sqrt{ }$ & \# & $\sqrt{ }$ & \# & $\sqrt{ }$ & \# & \# & \# & \# & \# & \# & \# & 11 & 91.6 & Yes \\
\hline Raine (1994) & $\sqrt{ }$ & $\checkmark$ & $\checkmark$ & \# & \# & v & v & \# & $\sqrt{ }$ & $\checkmark$ & $\sqrt{ }$ & $\mathrm{X}$ & \# & \# & \# & $\checkmark$ & \# & $\mathrm{X}$ & \# & $\checkmark$ & \# & \# & \# & \# & \# & \# & \# & 10 & 83.3 & Yes \\
\hline Raine (1994b) & $\sqrt{ }$ & $\sqrt{ }$ & $\checkmark$ & \# & \# & $\sqrt{ }$ & $\sqrt{ }$ & \# & $\sqrt{ }$ & $\sqrt{ }$ & $\checkmark$ & $\mathrm{X}$ & \# & \# & \# & $\sqrt{ }$ & \# & $\sqrt{ }$ & \# & $\sqrt{ }$ & \# & \# & \# & \# & \# & \# & \# & 11 & 91.6 & Yes \\
\hline Sacco (2007) & $\sqrt{ }$ & $\sqrt{ }$ & $\checkmark$ & \# & \# & $\sqrt{ }$ & $\sqrt{ }$ & \# & $\sqrt{ }$ & $\sqrt{ }$ & $\checkmark$ & $\mathrm{X}$ & \# & \# & \# & $\checkmark$ & \# & $\mathrm{X}$ & \# & $\sqrt{ }$ & \# & \# & \# & \# & \# & \# & \# & 10 & 83.3 & Yes \\
\hline Sacco (2012) & $\sqrt{ }$ & $\sqrt{ }$ & $\checkmark$ & \# & \# & $\checkmark$ & $\sqrt{ }$ & \# & $\checkmark$ & $\sqrt{ }$ & $\sqrt{ }$ & $\sqrt{ }$ & \# & \# & \# & $\sqrt{ }$ & \# & $\sqrt{ }$ & \# & $\mathrm{X}$ & \# & \# & \# & \# & \# & \# & \# & 11 & 91.6 & Yes \\
\hline Salahzadeh (2014) & $\sqrt{ }$ & $\sqrt{ }$ & $\checkmark$ & \# & \# & $\checkmark$ & $\sqrt{ }$ & \# & $\sqrt{ }$ & $\sqrt{ }$ & $\checkmark$ & $\mathrm{X}$ & \# & \# & \# & $\sqrt{ }$ & \# & $\sqrt{ }$ & \# & $\sqrt{ }$ & \# & \# & \# & \# & \# & \# & \# & 11 & 91.6 & Yes \\
\hline Santos (2009) & $\sqrt{ }$ & $\checkmark$ & $\checkmark$ & \# & \# & $\sqrt{ }$ & $\sqrt{ }$ & \# & $\sqrt{ }$ & $\sqrt{ }$ & $\sqrt{ }$ & $\mathrm{X}$ & \# & \# & \# & $\sqrt{ }$ & \# & $\sqrt{ }$ & \# & $\sqrt{ }$ & \# & \# & \# & \# & \# & \# & \# & 11 & 91.6 & Yes \\
\hline Souza (2014) & $\sqrt{ }$ & $\sqrt{ }$ & $\checkmark$ & \# & \# & $\sqrt{ }$ & $\sqrt{ }$ & \# & $\sqrt{ }$ & $\sqrt{ }$ & $\sqrt{ }$ & $\mathrm{X}$ & \# & \# & \# & $\checkmark$ & \# & $\sqrt{ }$ & \# & $\sqrt{ }$ & \# & \# & \# & \# & \# & \# & \# & 11 & 91.6 & Yes \\
\hline Tavares (2013) & $\sqrt{ }$ & $\checkmark$ & $\checkmark$ & \# & \# & $\checkmark$ & $\sqrt{ }$ & \# & $\checkmark$ & $\mathrm{X}$ & $\checkmark$ & $\checkmark$ & \# & \# & \# & $\sqrt{ }$ & \# & $\mathrm{X}$ & \# & $\sqrt{ }$ & \# & \# & \# & \# & \# & \# & \# & 10 & 83.3 & Yes \\
\hline Yu Cho (2008) & $\sqrt{ }$ & $\mathrm{X}$ & $\mathrm{X}$ & \# & \# & $\checkmark$ & $\sqrt{ }$ & \# & $\sqrt{ }$ & $\sqrt{ }$ & $\sqrt{ }$ & $\mathrm{X}$ & \# & \# & \# & $\sqrt{ }$ & \# & $\sqrt{ }$ & \# & $\sqrt{ }$ & \# & \# & \# & \# & \# & \# & \# & 9 & 75 & Yes \\
\hline
\end{tabular}




\section{Studies evaluation}

To assess the methodological quality of studies included in this review, the Downs and Black scale (1998) (Downs \& Black, 1998) was used, which consists of a 27-item checklist that is answered with yes when the information is contemplated on the study (1 point) and no when the information is not ( 0 points). The option to use the Downs and Black scale was made because it is a flexible instrument that evaluates observational studies and clinic trials, in addition to its internal consistency (Downs \& Black, 1998) and reproducibility. Every item was applied to the clinic trials studies, however to the observational studies only 12 items of the scale were considered (Table 1) because the others referred to elements that can only be applied to clinic trials. The studies were classified with high methodological quality when checked at least $70 \%$ of the evaluation items (Silva \& Carvalho, 2015). As well as in the other stages, the methodological quality assessment was conducted independently by the same two evaluators and discrepancies were settled by consensus.

\section{Strength of evidence}

The strength of evidence in this review was analysed by the method of Best Evidence Synthesis, which has been used by many groups of researchers, including the Cochrane Back Review Group (Trinh, 2009) and consists of an alternative to the meta-analysis that determines the strength of evidence through the number and quality of included studies (Trinh, 2009).The following criteria were adopted to analyse the strength of evidence: strong evidence when many studies are classified as high methodological quality; moderate evidence when one study is classified as high methodological quality and one or more studies are classified as low methodological quality; limited evidence when one study is classified as high methodological quality and many studies are classified as low methodological quality; and no evidence when many studies are classified as low methodological quality (Van Tulder, Koes, \& Bouter, 1997).

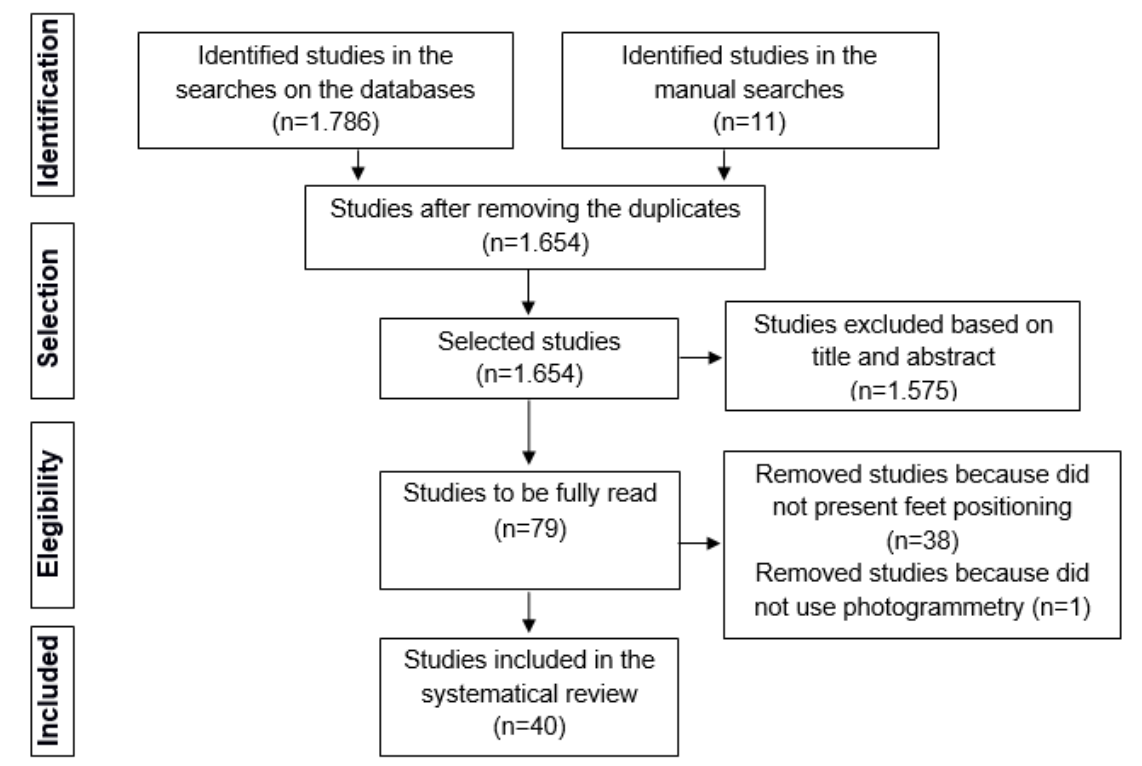

Figure 2. Flowchart of stages of studies inclusion according to PRISMA recommendations

\section{RESULTS}

It was found 1.786 studies in the five researched databases and 11 more were included through manual search. Of this total, 143 were duplicates, leaving 1.654 studies to be analysed in the title and abstract reading phase. In this stage, 1.575 studies did not present potential to fulfil the eligibility criteria, totalling 79 studies to be fully read. Of those, only 40 contemplated all eligibility criteria and were included in this review. The Figure 2 presents the flowchart of stages of inclusion on the systematic review according to PRISMA (Moher et al., 2009) recommendations. 
In the methodological quality assessment, only three studies had percentage $\leq 70 \%$, i.e., were classified as low methodological quality. The percentage and score of each study are presented in Table 1. Based on the Best Evidence Synthesis and number of articles classified as high methodological quality (37) and low methodological quality (3), this systematic review exhibits strong strength of evidence.

Table 2 presents the main methodological information of included studies. Although the methodology practically differs in all studies, the feet positioning was assembled in groups and the most common were: with inferior members in parallel and separated by a previously determined distance (Barbosa, Amorin, Zandonade, \& Delaprane, 2013; Belli, et al., 2009;Iunes, Cecílio, Dozza, \& Almeida, 2010; Iunes et al., 2005; Milanesi et al., 2011; Pezzan, João, Ribeiro, \& Manfio, 2011; Sacco et al., 2007; Sacco et al., 2012; Tavares et al., 2013); with the inferior members positioned together (Chiao Yi, Jardim, Inoue, \& Pignatari, 2008; Futlanetto, Chaise, Candotti, \& Loss, 2011; Furlanetto et al., 2012; Munhoz, Marquez, \& Siqueira, 2005); with the individual standing in self-referred or usual posture (Fedorak, Ashworth, Marshall, \& Paul, 2003; Gadotti \& Biasotto-Gonzalez, 2010; Gadotti, Armijo-Olivo, Silveira, \& Magee, 2013; Raine \& Towmey, 1994a; Raine \& Towmey, 1994b; Salazadeh et al., 2014; Yu Cho, 2007); and standardizing the individual usual posture by using the strategy of outlining the supporting base of each person to utilize as a mold for the photos (Coelho et al., 2013; Coelho et al., 2014; de Almeida et al., 2013; Dunk, Lalonde, \& Callaghan, 2005; Ferreira, Duarte, Maldonado, Bersanett, \& Marques, 2011; Figueiredo, Amaral, \& Shimano, 2012; Glaner, Mota, Viana, \& Santos, 2012; Lopes et al., 2014; Miranda, Schor, \& Girão, 2009; Pachioni et al., 2011; Souza, Pasinato, Corrêa, \& da Silva, 2014).

The studies included in this review evaluated children, teenagers and adults, some of them from specific populations such as mouth breathers (Chiao Yi et al., 2008; Corrêa \& Bérzin, 2007; Lima, Baraúna, Sologurem, Canto, \& Gastaldi, 2004; Milanesi et al., 2011) and people with temporomandibular joint disfunction
(Munhoz et al., 2005; Souza et al., 2014) (Table 2). Beyond that, most studies evaluated the frontal and sagittal planes and corporal posture almost completely, that is, evaluated parts of all corporal segments, using several software or protocols to obtain information about the individual posture, highlighting the software $\mathrm{PAS} / \mathrm{SAPO}$ that was used in 16 studies (Carregaro et al., 2012; Chiao Yi et al., 2008; Coelho et al., 2013; Coelho et al., 2014; de Almeida et al., 2013; Ferreira et al., 2011; Figueiredo et al., 2012; Glaner et al., 2012; Lopes et al., 2014; Milanesi et al., 2011; Pachioni et al., 2011; Pezzan et al., 2011; Santos, Silva, Sanada, \& Alves, 2009; Souza et al., 2014; Tavares et al., 2013) (Table 2).

\section{DISCUSSION}

According to the results of this review, there is a huge variety of feet positioning utilized to conduct a semi-static postural evaluation through photogrammetry, however it does not derail the execution of methodological comparisons, as most of the studies determine that the individual stands in a natural or self-referred posture for photos (Fedorak et al., 2003; Gadotti \& BiasottoGonzalez, 2010; Gadotti et al., 2013; Raine \& Towmey, 1994a; Raine \& Towmey, 1994b; Salazadeh et al., 2014; Yu Cho, 2007). According to Smith, Weiss, and Lehmkuhl (1997), the aligned posture is not natural because requires a conscious effort and an increase in muscular activity, so they suggest that the standard feet positioning prioritize body comfort and relaxation instead of a previously determined body alignment.

Although Bullock-Saxton (1993) and Lapierre (1982) sustain that only the comfortable upright posture adopted by the individual in the moment of evaluation is the true representative of body alignment, the use of a previously determined supporting base before any evaluation starts is repeatedly utilized. The reason is based on the fact that any other protocol that does not utilize a previously determined position derails the comparison between another evaluation by the same individual (Ferreira et al., 2010; Watson, 1998). 
Table 2

Synthesis of the 40 studies included in the review, organized by alphabetical order

\begin{tabular}{|c|c|c|c|c|c|}
\hline $\begin{array}{l}\text { Lead author } \\
\text { (year) }\end{array}$ & Sample & Evaluated planes & $\begin{array}{l}\text { Type of protocol } \\
\text { or software used }\end{array}$ & Evaluated segments & Utilized feet positioning \\
\hline Barbosa (2013) & Women with breast cancer & Frontal (anterior and posterior) & $\begin{array}{l}\text { Software } \\
\text { CorelDraw }\end{array}$ & $\begin{array}{c}\text { Shoulder, Pelvis and Shoulder blade evenness, } \\
\text { Head, Torso, Superior and Inferior Spine, } \\
\text { Shoulder blade rotation and the distance of } \\
\text { Thales' triangle. }\end{array}$ & $\begin{array}{l}\text { Women positioned with their feet in parallel } \\
\text { standing on previously designed drawings. }\end{array}$ \\
\hline Batistão (2014) & Elementary schools' students & $\begin{array}{l}\text { Frontal (anterior and posterior) } \\
\text { and Sagittal (right and left) }\end{array}$ & PAS/PAS/SAPO & $\begin{array}{l}\text { Lateral and forward Head leaning, Shoulder } \\
\text { protraction, cervical lordosis, thoracic kyphosis } \\
\text { and low back lordosis. Another segment of } \\
\text { Head, Torso and inferior members. }\end{array}$ & Feet aligned according to the width of the hip. \\
\hline Belli (2009) & $\begin{array}{l}\text { Asthmatic and non-Asthmatic } \\
\text { children }\end{array}$ & \begin{tabular}{|c|}
$\begin{array}{c}\text { Frontal (anterior and posterior) } \\
\text { Sagittal (three photos) and } \\
\text { zoom in the face }\end{array}$ \\
\end{tabular} & $\begin{array}{l}\text { ALCimage-2000 } \\
\text { Image-Editing } \\
\text { Software v1.5 }\end{array}$ & Every corporal posture & $\begin{array}{l}\text { Feet in parallel and separated by a piece of } \\
\text { polystyrene to standardize the supporting base } \\
\text { positioning. }\end{array}$ \\
\hline Carregaro (2012) & Brazil Public servants & $\begin{array}{c}\text { Frontal (anterior and posterior) } \\
\text { and Sagittal (right and left) }\end{array}$ & PAS/PAS/SAPO & $\begin{array}{c}\text { Head, pelvis, shoulder blade, knee, inferior } \\
\text { members/ankles/feet }\end{array}$ & Feet in parallel adopting the orthostatic position. \\
\hline Cerruto (2012) & $\begin{array}{l}\text { Children with quick palatal } \\
\text { expansion }\end{array}$ & $\begin{array}{l}\text { Frontal (anterior and posterior) } \\
\text { and Sagittal (only right) }\end{array}$ & AutoCAD2008 & Shoulder girdle, Shoulders, Head & $\begin{array}{l}\text { Feet positioned within } 30^{\circ} \text { using a mold as } \\
\text { reference. }\end{array}$ \\
\hline Chiao Yi (2008) & $\begin{array}{c}\text { Children with mouth and nose } \\
\text { breathing }\end{array}$ & Sagittal (only left) & PAS/PAS/SAPO & $\begin{array}{l}\text { Cervical and Low back lordosis, Thoracic } \\
\text { kyphosis and pelvis position. }\end{array}$ & Feet united and in parallel. \\
\hline Coelho (2013) & Children and teenagers & $\begin{array}{l}\text { Frontal posterior) and Sagittal } \\
\text { (only left) }\end{array}$ & PAS/PAS/SAPO & $\begin{array}{l}\text { Head, shoulder, pelvis, knee, malleolus and body } \\
\text { asymmetry. }\end{array}$ & $\begin{array}{l}\text { With the feet comfortably positioned, the } \\
\text { supporting base of each standing individual was } \\
\text { outlined in a 30x40cm paper sheet to be used as a } \\
\text { mold for the photos. }\end{array}$ \\
\hline Coelho (2014) & Children in school age & $\begin{array}{l}\text { Frontal (anterior) and Sagittal } \\
\text { (only left) }\end{array}$ & PAS/PAS/SAPO & $\begin{array}{l}\text { Head, shoulder, knee, pelvis and malleolus } \\
\text { alignment. Body symmetry, anteriorization of } \\
\text { the Head, Shoulder protrusion and } \\
\text { anteroposterior corporal leaning. }\end{array}$ & $\begin{array}{c}\text { With the feet comfortably positioned, the } \\
\text { supporting base of each standing individual was } \\
\text { outlined in a 30x40cm paper sheet to be used as a } \\
\text { mold for the photos. }\end{array}$ \\
\hline Corrêa (2007) & Children with mouth breathing & $\begin{array}{l}\text { Frontal (anterior and posterior) } \\
\text { and Sagittal (only right) }\end{array}$ & $\begin{array}{l}\text { ALCimage } \\
\text { Software }\end{array}$ & Shoulder blade, Shoulder, Head and Collarbone. & $\begin{array}{c}\text { Feet positioned within } 30^{\circ} \text { as the individual } \\
\text { stands in a comfortable position. }\end{array}$ \\
\hline $\begin{array}{l}\text { de Almeida } \\
\text { (2013) }\end{array}$ & Asthmatic adults & $\begin{array}{l}\text { Frontal (anterior and posterior) } \\
\text { and Sagittal (right and left) }\end{array}$ & PAS/PAS/SAPO & \begin{tabular}{|} 
Vertical and horizontal head alignment, angle \\
between acromion and anterior superior iliac \\
spine, anterior superior iliac spine horizontal \\
alignment, horizontal symmetry between T3 and \\
shoulder blade, vertical and horizontal torso \\
alignment, vertical body alignment, horizontal \\
pelvis alignment, angle between knee and ankle \\
\end{tabular} & $\begin{array}{l}\text { Feet positioned on a previously designed } \\
\text { supporting base in a paper sheet as its rotated to } \\
\text { obtain photos of all planes. }\end{array}$ \\
\hline Dunk (2005) & Young adults & $\begin{array}{l}\text { Frontal (anterior) and Sagittal } \\
\text { (only right) }\end{array}$ & $\begin{array}{l}\text { Software } \\
\text { developed by the } \\
\text { university of } \\
\text { Waterloo } \\
\text { (nameless) }\end{array}$ & $\begin{array}{l}\text { Cervical, Thoracic and Lumbar spine, Head, } \\
\text { Shoulder and pelvis }\end{array}$ & $\begin{array}{l}\text { Feet positioned on a paper sheet with the } \\
\text { individuals standing upright and relaxed as the } \\
\text { outline is drawn to be used as a mold for the } \\
\text { photos. }\end{array}$ \\
\hline
\end{tabular}




\begin{tabular}{|c|c|c|c|c|c|}
\hline Fedorak (2003) & Adults with and without pain & $\begin{array}{l}\text { Frontal (anterior) and Sagittal } \\
\text { (only right) }\end{array}$ & $\begin{array}{l}\text { Qualitative } \\
\text { evaluation }\end{array}$ & Cervical and Low back & $\begin{array}{l}\text { Feet in natural position (self-referred) as the } \\
\text { individuals stand in natural posture with their } \\
\text { hands next to the body. }\end{array}$ \\
\hline Ferreira (2011) & Young adults & $\begin{array}{l}\text { Frontal (anterior and posterior) } \\
\text { and Sagittal (right and left) }\end{array}$ & PAS/PAS/SAPO & Every corporal posture & $\begin{array}{l}\text { Feet positioned on a carpet, in which the outline } \\
\text { was drawn to be used as a mold for photos in } \\
\text { every plane. }\end{array}$ \\
\hline $\begin{array}{l}\text { Figueiredo } \\
\quad(2012)\end{array}$ & $\begin{array}{l}\text { Brazil Air Force academy cadets and } \\
\text { pilots }\end{array}$ & $\begin{array}{l}\text { Frontal (posterior) and Sagittal } \\
\text { (only right) }\end{array}$ & PAS/PAS/SAPO & $\begin{array}{c}\text { Head, acromion and antero superior iliac spine } \\
\text { horizontal alignment and Head vertical } \\
\text { alignment. }\end{array}$ & $\begin{array}{l}\text { Feet positioned on a rubber carpet that already } \\
\text { had a previously design of footprints to be used as } \\
\text { a supporting base. }\end{array}$ \\
\hline Fortin (2010) & Teenagers diagnosed with scoliosis & $\begin{array}{l}\text { Frontal (anterior and posterior) } \\
\text { and Sagittal (right and left) }\end{array}$ & $\begin{array}{l}\text { Non-stated } \\
\text { Software }\end{array}$ & $\begin{array}{l}\text { Pelvis, Thoracic, lumbar and thoraco-lumbar } \\
\text { spine, torso, shoulder blade and shoulders. }\end{array}$ & $\begin{array}{l}\text { Feet positioned with the assistance of two } 30^{\circ} \\
\text { triangles drawn on the ground as the individuals } \\
\text { stand comfortably. }\end{array}$ \\
\hline Fortin (2012) & Teenagers diagnosed with scoliosis & $\begin{array}{l}\text { Frontal (anterior and posterior) } \\
\text { and Sagittal (right and left) }\end{array}$ & $\begin{array}{l}\text { Non-stated } \\
\text { Software }\end{array}$ & Every corporal posture & $\begin{array}{l}\text { Feet positioned with the assistance of two } 30^{\circ} \\
\text { triangles drawn on the ground as the individuals } \\
\text { stand comfortably. }\end{array}$ \\
\hline $\begin{array}{l}\text { Furlanetto } \\
(2011)\end{array}$ & Academic adults & $\begin{array}{l}\text { Frontal (anterior) and Sagittal } \\
\text { (only right) }\end{array}$ & APPID & $\begin{array}{c}\text { Corporal balance and cervical, thoracic, lumbar } \\
\text { and scoliotic arrows }\end{array}$ & Feet and knees set according to the images \\
\hline $\begin{array}{l}\text { Furlanetto } \\
(2012)\end{array}$ & Children diagnosed with scoliosis & Frontal (anterior) & DIPA & Scoliosis & $\begin{array}{l}\text { Feet and knees set according to the knees natural } \\
\text { posture of the individual. }\end{array}$ \\
\hline Gadotti (2010) & Female physiotherapy academics & Sagittal (only left) & Alcimage Software & Head posture & $\begin{array}{l}\text { Feet in natural position (self-referred) as the } \\
\text { individuals stand relaxed after the standardization } \\
\text { of Head posture (Cervical flexion and extension). }\end{array}$ \\
\hline Gadotti (2013) & Healthy women & Sagittal (only left) & Alcimage Software & Head posture & $\begin{array}{l}\text { Feet in natural position (self-referred) as the } \\
\text { individuals stand relaxed after the standardization } \\
\text { of Head posture (Cervical flexion and extension). }\end{array}$ \\
\hline Glaner (2012) & Women & $\begin{array}{l}\text { Frontal (anterior and posterior) } \\
\text { and Sagittal (right and left) }\end{array}$ & PAS/PAS/SAPO & Every corporal posture & $\begin{array}{l}\text { Feet positioned on an ethyl vinyl acetate carpet, in } \\
\text { which its outline was drawn to be used as mold } \\
\text { for the photos. }\end{array}$ \\
\hline $\begin{array}{c}\text { Hanuskiewicz } \\
(2015)\end{array}$ & $\begin{array}{c}\text { Women after breast cancer } \\
\text { treatment }\end{array}$ & Sagittal (only one side) & \begin{tabular}{|c|} 
Computer Body \\
Posture Diagnosis
\end{tabular} & Spine curvature & $\begin{array}{c}\text { Feet in parallel with their heels aligned as the } \\
\text { individuals stand freely. }\end{array}$ \\
\hline Iunes (2005) & Academics & \begin{tabular}{|l|} 
Frontal (anterior and posterior), \\
Sagittal (only one side) and face
\end{tabular} & $\begin{array}{c}\text { ALCimage } \\
\text { Software } 2000\end{array}$ & Every corporal posture & Feet separated by a $7.5 \mathrm{~cm}$ rectangle \\
\hline Iunes (2010) & In patients with idiopathic scoliosis & $\begin{array}{c}\text { Frontal (anterior and posterior) } \\
\text { and right Sagittal (upright and } \\
\text { flexed) }\end{array}$ & Alcimage Software & Every corporal posture & $\begin{array}{c}\text { Feet separated by a } 7.5 \mathrm{~cm} \text { ethyl vinyl acetate } \\
\text { rectangle. }\end{array}$ \\
\hline Lima (2004) & $\begin{array}{c}\text { Children with obstructed mouth } \\
\text { breathing, Children with functional } \\
\text { mouth breathing and Children with } \\
\text { nose breathing }\end{array}$ & $\begin{array}{c}\text { Frontal (anterior and posterior) } \\
\text { and Sagittal (only left) }\end{array}$ & $\begin{array}{c}\text { Alcimage Software } \\
2\end{array}$ & Every corporal posture & $\begin{array}{c}\text { Feet aligned with an opening of } 36^{\circ} \text { between their } \\
\text { hindfeet as the individuals stand in orthostatic } \\
\text { position. }\end{array}$ \\
\hline Lopes (2014) & Under ages with Acromegaly & $\begin{array}{l}\text { Frontal (anterior and posterior) } \\
\text { and Sagittal (right and left) }\end{array}$ & PAS/SAPO & Every corporal posture & $\begin{array}{c}\text { Feet positioned on a previously designed drawing } \\
\text { of their own feet as they stood comfortably in } \\
\text { their natural feet position. }\end{array}$ \\
\hline
\end{tabular}




\begin{tabular}{|c|c|c|c|c|c|}
\hline Munhoz (2005) & $\begin{array}{l}\text { Adults with temporomandibular } \\
\text { joint disfunction }\end{array}$ & $\begin{array}{c}\text { Frontal (anterior and posterior), } \\
\text { Sagittal (only one side) and } \\
\text { zoom in the face. }\end{array}$ & CorelDraw 9.0 & $\begin{array}{l}\text { Pelvis, shoulder blade, shoulders, head and } \\
\text { thoracic, cervical and lumbar spine }\end{array}$ & $\begin{array}{l}\text { Feet set on a } 30 \mathrm{~cm} \text { stool as the individuals stand } \\
\text { in the orthostatic position. }\end{array}$ \\
\hline Milanesi (2011) & $\begin{array}{l}\text { Adults with mouth and nose } \\
\text { breathing }\end{array}$ & $\begin{array}{c}\text { Frontal (anterior and posterior) } \\
\text { and Sagittal (only right) }\end{array}$ & PAS/SAPO & Every corporal posture & $\begin{array}{l}\text { Feet separated and in parallel positioned on a } \\
\text { drawing in a box according to the images. }\end{array}$ \\
\hline Miranda (2009) & Women with chronic pelvic pain & $\begin{array}{l}\text { Frontal (anterior and posterior) } \\
\text { and Sagittal (right and left) }\end{array}$ & CorelDraw 11.0 & Every corporal posture & $\begin{array}{c}\text { As the women stand in a familiar and comfortable } \\
\text { position with their feet on a carpet, its outline } \\
\text { was drawn after the first photo to be used as a } \\
\text { mold for the other photos. }\end{array}$ \\
\hline Pachioni (2011) & $\begin{array}{l}\text { Individuals with a chronic } \\
\text { obstructive lung disease }\end{array}$ & $\begin{array}{l}\text { Frontal (anterior) e Sagittal } \\
\quad \text { (right and left) }\end{array}$ & PAS/SAPO & $\begin{array}{c}\text { Pelvis, head, shoulders, shoulder blade, kyphosis } \\
\text { and torso }\end{array}$ & $\begin{array}{l}\text { Feet positioned freely on a cardboard as its } \\
\text { outline was drawn after the first photo to be used } \\
\text { as a mold for other photos. }\end{array}$ \\
\hline Pezzan (2011) & Teenagers that wore high heels & Sagittal (only right by image) & PAS/SAPO & Lumbar lordosis and Pelvic angle alignment & $\begin{array}{c}\text { Feet separated by a } 7.5 \mathrm{~cm} \text { ethyl vinyl acetate } \\
\text { rectangle. }\end{array}$ \\
\hline Raine (1994) & $\begin{array}{l}\text { People with scoliosis that haven't } \\
\text { gone through treatment our surgery }\end{array}$ & Sagittal (only left) & Non-stated & $\begin{array}{c}\text { Superior and inferior thoracic spine and Superior } \\
\text { and inferior lumbar spine }\end{array}$ & $\begin{array}{c}\text { Feet in a comfortable position (self-referred) as } \\
\text { the individuals stand with their weight equally } \\
\text { divided on both legs, straight knees, arms next to } \\
\text { the body and looking forward }\end{array}$ \\
\hline Raine (1994 b) & Healthy adults & $\begin{array}{l}\text { Frontal (posterior) and Sagittal } \\
\text { (only left) }\end{array}$ & Non-stated & Head, shoulders and thoracic spine & Feet in a comfortable position (self-referred) \\
\hline Sacco (2007) & Adults & $\begin{array}{l}\text { Frontal (anterior and posterior) } \\
\text { and Sagittal (right and left) }\end{array}$ & $\begin{array}{l}\text { PAS/SAPO e } \\
\text { CorelDraw v12 } \\
\end{array}$ & $\begin{array}{l}\text { Tibiotarsal angle, flexion and extension knee } \\
\text { angle, Q angle and hindfeet angle. }\end{array}$ & $\begin{array}{c}\text { Feet separated by a } 7 \times 30 \mathrm{~cm} \text { ethyl vinyl acetate } \\
\text { rectangle. }\end{array}$ \\
\hline Sacco (2012) & Young adults & Frontal (anterior) & Photoshop v. 7.0 & Hindfeet angle & $\begin{array}{c}\text { Feet separated by a } 7.5 \mathrm{~cm} \text { ethyl vinyl acetate } \\
\text { rectangle. }\end{array}$ \\
\hline $\begin{array}{l}\text { Salahzadeh } \\
\quad(2014)\end{array}$ & Young adult women & Sagittal (only left) & Adobe Acrobat & Head and neck & $\begin{array}{l}\text { Feet in natural position as the individuals stand } \\
\text { relaxed after the standardization of Head posture } \\
\text { (Cervical flexion and extension). }\end{array}$ \\
\hline Santos (2009) & $\begin{array}{c}\text { Healthy } 7,8,9 \text { or } 10 \text { years old } \\
\text { children }\end{array}$ & $\begin{array}{l}\text { Frontal (anterior and posterior) } \\
\text { and Sagittal (right and left) }\end{array}$ & PAS/SAPO & Every corporal posture & $\begin{array}{l}\text { The individual marched on a cardboard for } 10 \\
\text { seconds as the plantigrade print was registered to } \\
\text { preserve the position and dimension of the base } \\
\text { in the different evaluated planes. }\end{array}$ \\
\hline Souza (2014) & $\begin{array}{l}\text { Individuals with temporomandibular } \\
\text { joint disfunction }\end{array}$ & $\begin{array}{c}\text { Frontal (anterior and posterior) } \\
\text { and Sagittal (only left) }\end{array}$ & PAS/SAPO & Every corporal posture & $\begin{array}{l}\text { As the individuals stand in usual posture with } \\
\text { their feet positioned on a rubber carpet, its } \\
\text { outline was drawn after the first photo to be used } \\
\text { as a mold for the other photos }\end{array}$ \\
\hline Tavares (2013) & Elderly people & $\begin{array}{l}\text { Frontal (anterior and posterior) } \\
\text { and Sagittal (right and left) }\end{array}$ & $\mathrm{PAS} / \mathrm{SAPO}$ & Every corporal posture & $\begin{array}{l}\text { Feet separated by } 10 \mathrm{~cm} \text { and in parallel with that } \\
\text { distance being marked on the ground with tape. }\end{array}$ \\
\hline Yu Cho (2008) & Chinese teenagers & $\begin{array}{l}\text { Frontal (anterior and posterior) } \\
\text { and Sagittal (only left) }\end{array}$ & Non-stated & Spine and shoulder curvatures & $\begin{array}{l}\text { Feet in a comfortable position (self-referred) as } \\
\text { the individuals stand upright and relaxed. }\end{array}$ \\
\hline
\end{tabular}


However, this standardization is still fairly vague, and the literature does not answer this question with certainty as it is proven by the many feet positioning found in the studies. The most mentioned standardization is the strategy of standardize the self-referred position of each individual. To do that, the evaluators request that before the first photograph the individuals stand comfortably on a paper sheet, cardboard or carpet. After that procedure, the evaluator outlines their feet to obtain a mold for position in the evaluation. Every time that there is a change in the photo plane, the mold is rotated to the desired position and the individual is relocated to step on the previously determined drawing. (Coelho et al., 2013; Coelho et al., 2014; de Almeida et al., 2013; Dunk, Lalonde, \& Callaghan, 2005; Ferreira, Duarte, Maldonado, Bersanett, \& Marques, 2011; Figueiredo, Amaral, \& Shimano, 2012; Glaner, Mota, Viana, \& Santos, 2012; Lopes et al., 2014; Miranda, Schor, \& Girão, 2009; Pachioni et al., 2011; Souza, Pasinato, Corrêa, \& da Silva, 2014). This manoeuvre might be efficient in reproducibility studies, nevertheless when adopted to only one evaluation, its standardization may be questioned because the usual intention is to evaluate the individual in its natural posture.

Another well-established pattern of foot positioning utilizes the lower limbs positioned in parallel and apart (Barbosa et al., 2013; Belli et al., 2009; Iunes et al., 2005; Iunes et al., 2010; Milanesi et al., 2011; Pezzan et al., 2011; Sacco et al., 2007; Sacco et al., 2012; Tavares et al., 2013). One example of protocol that utilizes that type of position for photogrammetry is the classical study by Kendall et al. (1995) which believes that postural evaluation should be conducted with a supporting base with the individual's feet in parallel, their heels separated by a $7.5 \mathrm{~cm}$ distance and the hind feet abducted $8^{\circ}$ to $10^{\circ}$ from the median line. For Ferreira et al., (2010), the distances between the anatomical references of the feet, such as heels and medial malleolus, are measures that do not correctly manifest a supporting base because they do not quantify the possible rotation in the feet positioning, being only valid to quantify valgus knee.
It is common to find studies that do not denote the position of evaluated inferior members clearly, such as the study of Batistão et al. (2014), which requires the individuals to align their feet according to the width of their hip and the study of Hanuskiewicz et al. (2015), that requires the individuals to stand freely with their feet in parallel and heels aligned. Both studies do not determine angles or distances between feet, which might be considered a lack of rigor in the protocol's methodology and produce misleading results in the evaluation.

The positioning of inferior members as a set, considering knees and feet, provides a more obtuse supporting base and is also utilized for postural evaluation through photogrammetry (Chiao Yi et al., 2008; Furlanetto et al., 2011; Furlanetto et al., 2012; Munhoz et al., 2005). In that position of inferior members, it is important that knees are aligned. For example, if the individual has a space between the knees when its malleolus are touching, the individual should stay with the malleolus united and the rest of inferior members in the most comfortable position; if the individual has a space between the malleolus when its knees are touching, the individual should stay with the knees united and preserve its physiological space between malleolus; and if the individual succeed in aligning knees and malleolus simultaneously, that position should be adopted (Watson, 1998). The option for this standardization protocol of feet positioning ensures the maintenance of valgus knee standards. In case the evaluator does not observe the individual's position, it might mask the results of some evaluation segments, even because of the discomfort that may be generated in the individual.

Only one study of all found used a dynamic standardization to determine the feet positioning for the semi-static postural evaluation. Santos et al., (2009) requires the individual to march, i.e., to execute some type of static walk on a cardboard, in which the plantigrade print of the feet positioning is registered to be utilized as a mold for the photos. For Santos (2011), the feet position of a step should be utilized as it is more functional and unique for each individual and because when feet are in parallel, the hip joints 
rotates internally, the great trochanters go forward and the muscles within this space are tensioned, as this tension pulls its near insertions in the femur direction and provokes a small retraction of the pelvis and the internal rotation of femoral condyles, patella and malleolus, it is impossible to know the position that those segments really adopt in the orthostatic physiological posture.

In summary, though many of feet positioning to conduct a semi-static postural evaluation through photogrammetry were found, none of the studies compared their results in different feet positioning. Therefore, it is considered that is not possible yet to affirm which is the best feet positioning to be adopted in a postural evaluation, as the decision still depends on the professional and its experience and objectives. The diversity of protocols of postural evaluation, as well as the lack of detailed description for an ideal understanding of data collection procedure, limits a complex discussion about the topic.

\section{CONCLUSION}

The positioning of feet using the strategy of standardizing the self-reported position of each individual has been the most used in the studies. However, based on the results, it is still not possible to state that this is the most adequate foot positioning for use in the semi-static postural evaluation through photogrammetry. Considering that this systematic review presents strong evidence and that there is currently no single foot position considered to be ideal, it is considered primordial that the selection of evaluation methodology respects the specific instructions of each analysis protocol or software used to conduct a semi-static postural evaluation through photogrammetry, such as its procedures and particularities. Experimental studies are still necessary to obtain accurate information about the best positioning of feet for this type of evaluation.

Acknowledgments:

Nothing to declare.

Conflict of interests:

Nothing to declare.
Funding:

Nothing to declare.

\section{REFERENCES}

Barbosa, J. A. N., Amorin, M. H. C., Zandonade, E., \& Delaprane, M. L. (2013). Avaliação da postura corporal em mulheres com câncer de mama. Revista Brasileira de Ginecologia e Obstetetricia, 35(5), 215-20.

Batistão, M. V., Carnaz, L., Barbosas L. F., da Motta, G. C., \& Sato, T. O. (2014). Posture and musculoskeletal pain in eutrophic, overweighed, and obese student: A cross-sectional study. Motriz, 20(2), 192-199.

Belli, J. F., Chaves, T. C., de Oliveira, A. S., \& Grossi, D. B. (2009). Analysis of body posture in children with mild to moderate asthma. European Journal of Pediatrics, 168(10), 1207-16.

Bullock-Saxton, J. (1993). Postural alignment in standing: a repeatability study. Australian Physiotherapy, 39(1)25-29.

Carregaro, R., Falcão, J., Massuda, K., Masunaga, D., Sinzato, C., de Oliveira, A. B., \& Padula, R. S. (2012). Postural analysis and psychosocial measurements of federal civil servants of an institution of higher education. Work, 41 (Suppl 1), 4795-4800.

Cerruto, C., Di Vecce, L., Doldo, T., Giovanetti, A., Polimeni, A., \& Goracci, C. (2012). A computerized photographic method to evaluate changes in head posture and scapular position following rapid palatal expansion: A pilot study. Journal of Clinical Pediatric Dentistry, 37(2), 213218.

Chiao Yi, L., Jardim, J. R., Inoue, D. P., \& Pignatari, S. S. N. (2008). Relationship between excursion of the diaphragm and curvatures of the spinal column in mouth breathing children. Journal of Pediatrics, 84(2), 171-177.

Coelho, J. J., Graciosa, M. D., De Medeiros, D. L., Da Costa, L. M. R., Martinello, M., \& Ries, L. G. K. (2013). Influence of nutritional status and physical activity on the posture of children and adolescents. Fisioterapia e Pesquisa, 20(2), 136-142.

Coelho, J. J., Graciosa, M. D., de Medeiros, D. L., Pacheco, S. C. S., da Costa, L. M. R., \& Ries, L. G. K. (2014). Influence of flexibility and gender on the posture of school children. Revista Paulista de Pediatria, 32 (3), 233-228.

Corrêa, E. C. R, \& Bérzin, F. (2007). Efficacy of physical therapy on cervical muscle activity and on body posture in school-age mouth breathing children. International Journal of Pediatric Otorhinolaryngology, 71(10), 1527-1535.

de Almeida, V. P., Guimarães, F. S., Moço, V. J. R., Ferreira, A. S., Menezes, S. L., \& Lopes, A. J. (2013). Is there an association between postural balance and pulmonary function with asthma? Clinics, 68(11), 1421-1427. 
Downs, S. H., Black, N. (1998). The feasibility of creating a checklist for the assessment of the methodological quality both of randomised and non-randomised studies of health care interventions. Journal of Epidemiology and Community Health, 52(6),377-84.

Dunk, N. M., Lalonde, J., \& Callaghan, J. P. (2005). Implications for the use of postural analysis as a clinical diagnostic tool: reliability of quantifying upright standing spinal postures from photographic images. Journal of Manipulative and Physiological Therapeutics, 28(6), 386-92.

Fedorak, C., Ashworth, N., Marshall, J., \& Paull, H. (2003). Reliability of the visual assessment of cervical and lumbar lordosis: How good are we? Spine, 28(16), 1857-9.

Ferreira, E. A., Duarte, M., Maldonado, E. P., Bersanett, A. A., \& Marques, A. P. (2011). Quantitative assessment of postural alignment in young adults based on photographs of anterior, posterior, and lateral views. Journal Manipulative and Physiological Therapeutics, 34(6), 371-80.

Ferreira, E. A. G., Duarte, M., Maldonado, E. P., Burke, T. N., \& Marques, A. P. (2010). Postural assessment software (PAS/SAPO): validation and reliability. Clinics, 65(7), 675-681.

Figueiredo, R. V., Amaral, A. C., \& Shimano, A. C. (2012). Photogrammetry on the identification of postural asymmetries in cadets and pilots of the Brazilian air force academy. Revista Brasileira de Fisioterapia, 16(1), 54-60.

Fortin, C., Feldman, D. E., Chariet, F., Gravel, D., Gauthier, F., \& Labelle, H. (2012). Reliability of a quantitative clinical posture assessment tool among persons with idiopathic scoliosis. Physiotherapy, 98(1), 64-75.

Fortin, C., Feldman, D. E., Chariet, F., \& Labelle, H. (2010). Validity of a quantitative clinical measurement tool of trunk posture in idiopathic scoliosis. Spine, 35(19), E988-E994.

Furlanetto, T. S., Candotti, C. T., Comerlato, T., \& Loss, J. F. (2012). Validating a posture evaluation method developed using a Digital Image-based Postural Assessment (DIPA) software. Computer Methods and Programs in Biomed, 108(1), 203-212.

Furlanetto, T. S., Chaise, F. O., Candotti, C. T., \& Loss, J. F. (2011). Fidedignidade de um protocolo de avaliação postural. Revista de Educação Física/UEM, $22(3), 411-419$.

Gadotti, I. C., Armijo-Olivo, S., Silveira, A., \& Magee, D. (2013). Reliability of the craniocervical posture assessment: visual and angular measurements using photographs and radiographs. Journal of Manipulative and Physiological Therapeutics, 36(9), 619-625.

Gadotti, I. C., \& Biasotto-Gonzalez, D. A. (2010). Sensitivity of clinical assessments of sagittal head posture. Journal of Evaluation in Clinical Practice, 16(1), 141-144.

Galvão, T. F., \& Pereira, M. G. (2014). Revisões sistemáticas da literatura: passos para sua elaboração. Epidemiologia e Serviços de Saúde, 23(1), 183-184.

Glaner, M. F., Mota, Y. L., Viana, A. C. R., \& Santos, M. C. (2012). Fotogrametria: Fidedignidade e falta de objetividade na avaliação postural. Motricidade, 8(1), 78-85.

Hanuskiewicz, J., Malicka, I., Barczyk-Pawelee, K., \& Wozniewski, M. (2015). Effects of selected forms of physical activity on body posture in the sagittal plane in women post breast cancer treatment. Journal of Back and Musculoskeletal Rehabilitation, 28(1), 35-42.

Higgins, J., \& Green, S. (2011). Cochrane handbook for systematic reviews of interventions $\left(5^{\text {th }} \quad\right.$ ed.). Chichester: John Wiley \& Sons.

Iunes, D. H., Castro, F. A., Salgado, H. S., Moura, I.C., Oliveira, A, S., \& Bevilaqua-Grossi, D. (2005). Intra and interexaminer reliability and method repeatability of postural evaluation via photogrammetry. Revista Brasileira de Fisioterapia, 9(3), 327-334.

Iunes, D. H., Cecílio, M. B. B, Dozza, M. A., \& Almeidas P. R. (2010). Quantitative photogrammetric of the Klapp method for treating idiopathic scoliosis. Revista Brasileira de Fisioterapia, 14(2), 133-40.

Kendall, F. P., McCreary, K. E., \& Provence, P. G. (1995). Músculos: provas e funções. São Paulo: Manole.

Lapierre, A. (1992). A reeducação física (6 $6^{\text {th }}$ Ed., Vol. 1). São Paulo: Manole.

Lima, L. C. O., Baraúna, M. A., Sologurem, M. J. J., Canto, R. S. T., \& Gastaldi, A. C. Postural alterations in children with mouth breathing assessed by computerized biophotogrammetry. Journal of Applied Oral Science, 12(3), 232-7.

Lopes, A. J., da Silva, D. P. G., Kasuki, L., Gadelha, M, R., Camilo, G. B., \& Guimarães, F. S. (2014). Posture and balance control in patients with acromegaly: Results of a cross-sectional study. Gait Posture, 40(1), 154-159.

Milanesi, J. M., Borin, G., Corrêa, E. C. R., da Silva, A. M. T, Bortoluzzi, D. C., \& Souza, J. A. (2011). Impact of the mouth breathing occurred during childhood in the adult age: Biophotogrammetric postural analysis. International Journal of Pediatric Otorhinolaryngology, 75(8), 999-1004.

Miranda, R., Schor, E., \& Girão, M. J. B. C. (2009). Avaliação postural em mulheres com dor pélvica crônica. Revista Brasileira de Ginecologia $e$ Obstetricia, 31 (7), 353-60.

Moher, D., Liberati, A., Tetzlaff, J., Altman, D. G., \& PRISMA Group. (2009). Preferred reporting items for systematic reviews and meta-analyses: the PRISMA statement. PLoS Medicine, 6(7), e1000097. https://doi.org/10.1371/journal.pmed.1000097

Moradi, N., Maroufi, N., Bijankhan, et al., (2014). Intrarater and Interrater Reliability of Sagittal Head Posture: A Novel Technique Performed by a Physiotherapist and a Speech and Language Pathologist. Journal of Voice, 28(6), 842-847. 
Munhoz, W. C., Marques, A. P., \& Siqueira, J. T. T. (2005). Evaluation of body posture in individuals with internal temporomandibular joint derangement. Cranio, 23(4), 269-278.

Pachioni, C. A. S., Ferrante, J. A., Panissa, T. S. D., Ferreira, D. M. A., Ramos, D., Moreira, G. L., \& Ramos, E. M. C. (2011). Avaliação postural em pacientes com doença pulmonar obstrutiva crônica. Fisioterapia e Pesquisa, 18(4), 341-5.

Pezzan, P. A. O., João, S. M. A., Ribeiro, A. P, \& Manfio, E. F. (2011). Postural assessment of lumbar lordosis and pelvic alignment angles on adolescent users and nonusers of high-heeled shoes. Journal of Manipulative and Physiological Therapeutics, 34(9), 614-621.

Raine, S., \& Twomey, L. T. (1994a). Validation of a non-invasive method of measuring the surface curvature of the erect spine. Journal of Manipulative and Physiological Therapeutics, 2(1), 11-21.

Raine, S., \& Twomey, L. T. (1994b). Posture of head, shoulfers and thoracic spine in comfortable erect standing. Australian Physiotherapy, 40(1), 25-32.

Sacco, I. C. N., Alibert, S., Queiroz, B. W. C., Pripas, D., Kieling, I., Kimura, A. A., ... Sera, M. T. (2007). Reliability of photogrammetry in relation to goniometry for postural lower limb assessment. Brazilian Journal of Physical Therapy, 11(5), 411-417. https://doi.org/10.1590/S141335552007000500013

Sacco, I. C. N., Picon, A. P., Ribeiro, A. P., Sartor, C. D., Camargo-Junior, F., Macedo, D. O., ... Aliberti, S. (2012). Effect of image resolution manipulation in rearfoot angle measurements obtained with photogrammetry. Brazilian Journal of Medical and Biological Research, 45(9), 806-810.

Salahzadeh, Z., Maroufi, N., Ahmadi, A., Behtash, H., Razmjoo, A., Gohari, M., \& Parnianpour, M. (2014). Assessment of forward head posture in females: Observational and photogrammetry methods. Journal of Back and Musculoskeletal Rehabilitation, 27(2), 131-139.
Santos, A. (2011). Diagnóstico clínico postural: um guia prático. São Paulo: Summus.

Santos, M. M., Silva, M. P. C., Sanada, L. S, \& Alves, C. R. J. (2009). Photogrammetric postural analysis on healthy seven to ten-year-old children: interrater reliability. Revista Brasileira de Fisioterapia, 13(4), 350-355.

Silva, F. F., \& Carvalho, J. F. (2015). Intensity of anticoagulation in the treatment of thrombosis in the antiphospholipid syndrome: a meta-analysis. Revista Brasileira de Reumatologia, 55(2), 159-166.

Smith, L. K., Weiss, E. L., \& Lehmkuhl, L. D. (1997) Cinesiologia Clínica de Brunnstrom ( $5^{\text {th }}$ ed.). São Paulo: Manole.

Souza, J. A., Pasinato, F., Corrêa, E. C. R., \& da Silva, A. M. T. (2014). Global body posture and plantar pressure distribution in individuals with and without temporomandibular disorder: a preliminary study. Journal of Manipulative and Physiological Therapeutics, 37(6), 407-14.

Tavares, G. M. S, da Rocha, T. R., do Espírito Santo, C. C., Piazza, L., Sperandio, F. F., Mazo, G. Z., \& Santos, G. M. (2013). Características posturais de idosos praticantes de atividade física. Scientia Medica, 23(4), 244-250.

Trinh, K. (2009). Summaries and recommendations of the global impression method. Journal of Acupucture and Tuina Science, 7(5), 296-302.

van Tulder, M. W., Koes, B. W., \& Bouter, L. M. (1997). Conservative treatment of acute and chronic nonspecific low back pain. A systematic review of randomized controlled trials of the most common interventions. Spine, 22(18), 21282156.

Watson, A. W. S. (1998). Procedure for the production of high quality 13. photographs suitable for the recording and evaluation of posture. Fisioterapia e Pesquisa, 5(1), 20-26.

Yu Cho, C. (2007). Survey of faulty posture and associated factors among Chinese adolescents. Journal of Manipulative and Physiological Therapeutics, 31(3), 224-229.

All content of Journal Motricidade is licensed under Creative Commons, except when otherwise specified and in content retrieved from other bibliographic sources. 